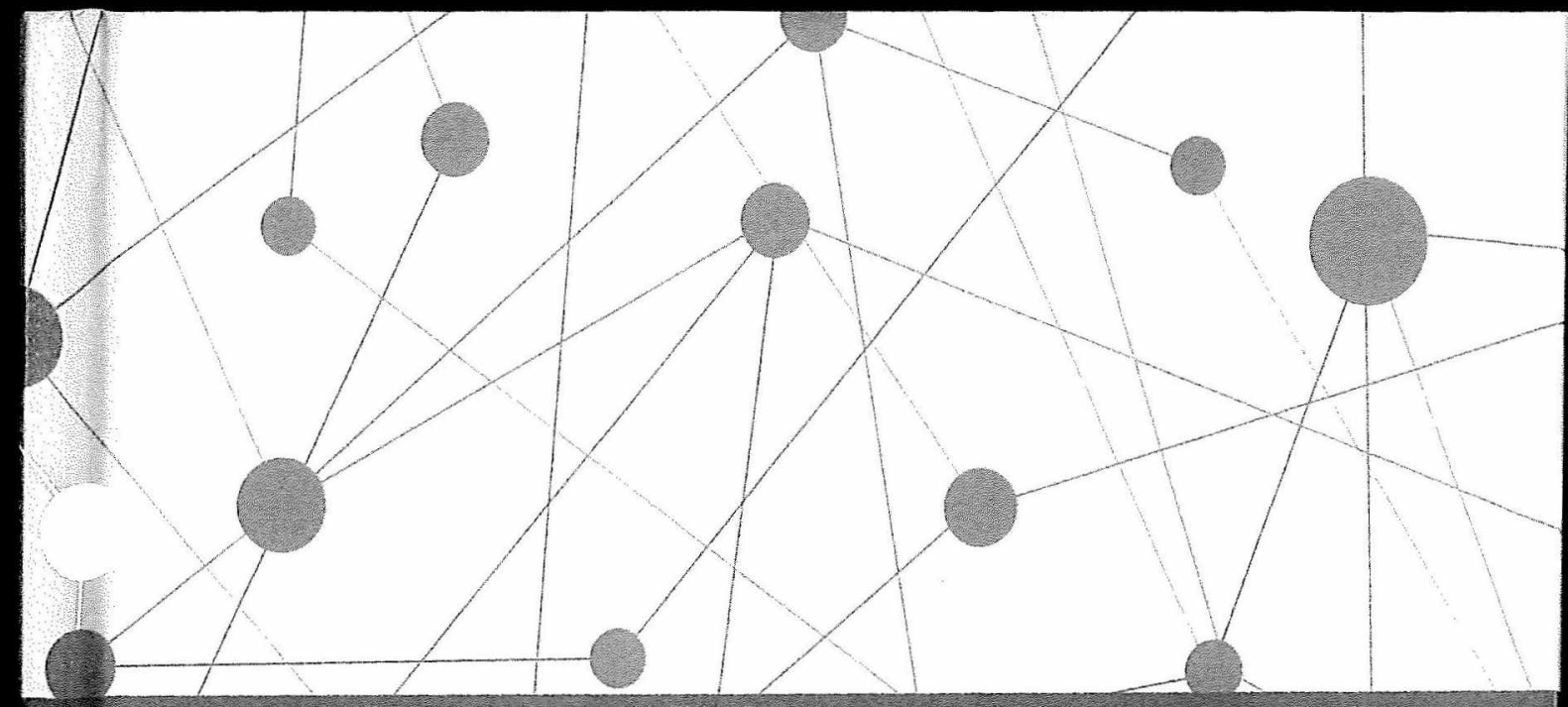

Rlountledge Rereanch in Spront, Culturne and Societsy

\title{
COMMUNITY SPORT AND SOCIAL INCLUSION
}

ENHANCING STRATEGIES FOR PROMOTING PERSONAL DEVELOPMENT, HEALTH AND SOCIAL COHESION

\section{Edited by}

Marc Theeboom, Hebe Schaillée, Rudi Roose,

Sara Willems, Emelien Lauwerier and Lieve Bradt

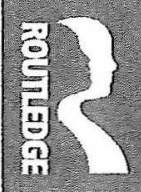




\section{Community Sport and Social Inclusion}

Enhancing Strategies for Promoting Personal Development, Health and Social Cohesion

\begin{tabular}{|c|c|}
\hline Social Activism in Women's Tennis & Sport and Secessionism \\
\hline Generations of Politics and Cultural & Edited by Mariann Vaczi and Alan \\
\hline Change & Bairner \\
\hline \multicolumn{2}{|l|}{ Kristi Trectway } \\
\hline & Discrimination in Football \\
\hline $\begin{array}{l}\text { Sport, Welfare and Social Policy in } \\
\text { the European Union }\end{array}$ & Christos Kassimeris \\
\hline Nicola R. Porro, Stefano Martelli and & Doping in Non-Olympic Sports \\
\hline Alberto Testa & $\begin{array}{l}\text { Challenging the Legitimacy of } \\
\text { WADA? }\end{array}$ \\
\hline Disability, the Media and the & Lovely Dasgupta \\
\hline \multicolumn{2}{|l|}{ Paralympic Games } \\
\hline Carolyn Jackson-Brown & $\begin{array}{l}\text { Social Capital and Sport } \\
\text { Organisations }\end{array}$ \\
\hline Sport, Film and National Culture & Richard Tacon \\
\hline Eattea by sean Crosson & Community Sport and Social \\
\hline Female Fans, Gender Relations and & Inclusion \\
\hline Football Fandom & Enhancing Strategies for Promoting \\
\hline Challenging the Brotherhood Culture & Personal Development, Health and \\
\hline Honorata Jakubowska, Dominik & Social Cohesion \\
\hline Antonowicz and Radostow & Edited by Marc Theeboom, Hebe \\
\hline Kossakowski & $\begin{array}{l}\text { Schaillée, Rudi Roose, Sara Willems, } \\
\text { Lieve Bradt and Emelien Lauwerier }\end{array}$ \\
\hline \multicolumn{2}{|l|}{ Gym Bodies } \\
\hline Exploring Fitness Cultures & Cricket and Contemporary Society \\
\hline James Brighton, Ian Wellard and Amy & in Britain \\
\hline Clark & Crisis and Continuity \\
\hline & Russell Holden \\
\hline
\end{tabular}

For more information about this series, please visit: www.routledge.com/sport series/RRSCS

\section{Edited by Marc Theeboom, Hebe Schaillée, Rudi Roose, Sara Willems, Emelien Lauwerier and Lieve Bradt}

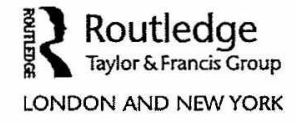


First published 2022

by Routledge

Park Square, Milton Park, Abingdon, Oxon OX14 4RN

and by Routledge

605 Third Avenue, New York, NY 10158

Routledge is an imprint of the Taylor \& Francis Group, an informa

business

O 2022 selection and editorial matter, Vrije Universiteit Brussel and

Universiteit Gent; individual chapters, the contributors

The right of Vrije Universiteit Brussel and Universiteit Gent to be

identified as the author of the editorial material, and of the authors for their

individual chapters, has been asserted in accordance with sections 77 and

78 of the Copyright, Designs and Patents Act 1988.

All rights reserved. No part of this book may be reprinted or reproduced or utilised in any form or by any electronic, mechanical, or other means, now known or hereatter invented, including photocopying and recording, or in any information storage or retrieval system, without permission in writing

Trademark notice: Product or corporate names may be trademarks or registered trademarks, and are used only for identification and explanation without intent to infringe.

British Library Cataloguing-in-Publication Data

A catalogue record for this book is available from the British Library

Library of Congress Cataloging-in-Publication Data

A catalog record for this book has been requested

ISBN: 978-0-367-35614-9 (hbk)

ISBN: $978-1-032-12528-2(\mathrm{pbk})$

DOI: $10.4324 / 9780429340635$

Typeset in Times New Roman

by Apex CoVantage, LLC

\section{Contents}

Contributors

PART 1

Introduction and general findings

1 Introduction

MARC THEEBOOM, HEBE SCHAILLEEE, DORIEN BROSENS, SARA

WILLEMS, EMELIEN LAUWERIER, RUDI ROOSE AND LIEVE BRADT

2 Community sport and social inclusion: necessary and sufficient conditions

HEBE SCHAILLEE, MARC THEEBOOM, SHANA SABBE, KAREN VAN DER VEKEN, PIETER DEBOGNIES AND DORIEN BROSENS

PART 2

Thematic insights into community sport and social inclusion

3 Reflective practices in a volunteer community sport coach training programme

DORIEN BROSENS, HEBE SCHAILLÉE, MARC THEEBOOM AND

PIETER DEBOGNIES

4 Health promotion in the context of community sport: illustration of a theory-informed approach to programme development and evaluation

EMELIEN LAUWERIER, KAREN VAN DER VEKEN, KAATJE VAN ROY
AND SARA WILLEMS 
5 Facilitating conditions for establishing social cohesion through structural approaches in community sport SHANA SABBE, LIEVE BRADT AND RUDI ROOSE

PART 3

Broader perspectives on community sport and social inclusion

6 The evolution of evaluation: from the black box to programme theory

FRED COALTER

7 Realist inquiry and action research GUY KEGELS AND BRUNO MARCHAL

8 Problematising the concept of social inclusion through sport: opportunities and challenges through the lens of aspirations and capabilities

EMRAN RIFFI ACHARKI AND RAMÓN SPAAIJ

\section{PART 4}

General reflections

\section{General reflections}

MARC THEEBOOM, HEBE SCHAILLÉE, SARA, WILLEMS, EMELIEN LAUWERIER, RUDI ROOSE AND LIEVE BRADT

\section{Contributors}

Emran Riffi Acharki, Amsterdam University of Applied Sciences and University of Amsterdam, the Netherlands

Lieve Bradt, Ghent University, Belgium

Dorien Brosens, Vrije Universiteit Brussel, Belgium

Fred Coalter, Vrije Universiteit Brussel, Belgium, and Leeds Beckett University, UK Pieter Debognies, Vlaams Instituut Gezond Leven, Belgium

Guy Kegels, Institute of Tropical Medicine, Belgium

Emelien Lauwerier, Ghent University, Belgium

Bruno Marchal, Institute of Tropical Medicine, Belgium

Rudi Roose, Ghent University, Belgium

Kaatje Van Roy, Ghent University, Belgium

Shana Sabbe, Ghent University, Belgium

Hebe Schaillée, Vrije Universiteit Brussel, Belgium

Ramón Spaaij, Victoria University and University of Amsterdam, the Netherlands

Marc Theeboom, Vrije Universiteit Brussel, Belgium

Karen Van der Veken, Ghent University, Belgium

Sara Willems, Ghent University, Belgium 